\title{
Intellectual Property Protection OF INDIGENOUS KNOWLEDGE: IMPLEMENTING INITIATIVES AT NATIONAL AND REGIONAL LEVELS
}

\author{
KANChANA KaRIYAWASAM* AND ScOTt GUY*
}

[This article highlights the fundamental importance of implementing both national and regional measures to protect indigenous intellectual property rights. The development of such measures provides countries with an opportunity to protect their traditional knowledge. The measures will be implemented according to each country's unique level of economic development. In particular, laws can be developed that are sensitive to, and take specific account of, the cultural, social, political and economic diversity of the enacting countries. In light of these issues, this article concludes that national and regional integration provides an excellent opportunity for furthering national and regional collaboration, harmonising policies, and synchronising interventions across borders. It finally argues that effective and instrumentally beneficial national and regional mechanisms are more likely to succeed in states with similar cultures, economies, and ecology.]

\section{INTRODUCTION}

There have been several government and regional initiatives in recent years that have sought to address the inadequacy of international law in relation to the protection of indigenous people's intellectual property. In particular, the

\footnotetext{
* Lecturer in Law, Griffith University, Brisbane and Adjunct Research Fellow, The Australian Centre for Intellectual Property in Agriculture (ACIPA) UQ.

* Lecturer in Law, Griffith University, Brisbane.
} 
recent demand for the effective protection of traditional knowledge has gained momentum through the introduction of national (sui generis) ${ }^{1}$ and regional regimes, which have been constructed on the basis of the special needs of individual countries - depending upon their particular cultural and political conditions. ${ }^{2}$ Since conventional intellectual property regimes are ineffective for protecting traditional knowledge, these national and regional approaches have involved the drafting of new laws which regulate access to genetic resources and empower indigenous peoples to implement their own customary law obligations, and confer upon traditional owners the right to prevent others from reproducing and misappropriating traditional indigenous knowledge.

This paper aims to provide an overview of the current governmental and regional initiatives and considers how indigenous knowledge is treated and protected under these existing measures. It advocates that any future regulatory framework that is to be developed should be sensitive and responsive to the distinctive national traditions and cultures of indigenous people.

\section{GOVERNMENT INITIATIVES}

At a distinctly national level, countries have taken different approaches towards the protection of traditional knowledge by implementing defensive sui generis systems. It is believed that sui generis regimes would be most appropriate to protect the holistic character of traditional knowledge, to tackle the problem of the illegal acquisition of genetic resources, and to adapt to countries' specific circumstances and priorities. ${ }^{3}$ The next section of the paper aims to discuss initial approaches that have been taken at national levels in addressing traditional knowledge. There is no claim to be exhaustive discussion regard to all provisions of the laws; rather the aim is to identify the underlying conception and scope of the rights conferred. For that purpose,

\footnotetext{
${ }^{1}$ A sui generis system implies a special system 'of its own kind.' In this case it would be a system specifically designed to protect indigenous rights. A sui generis system for traditional knowledge protection should not be confused with the sui generis system for plant variety protection stipulated in Article 27(3)(b) of the TRIPS Agreement.

2 S K Verma, 'Protecting Traditional Knowledge: Is a Sui Generis System an Answer?' (2004) 7 Journal of World Intellectual Property 765, 800.

${ }^{3}$ See the Report of the IGC Sixth Session, WIPO DOC, WIPO/GRTKF/IC/6/14, 14 April 2004.
} 
Brazil, Peru, Panama, and the Philippines have been taken as typical case studies.

Brazil was one of the first countries to establish a legal system (sui generis) specifically for the protection of traditional knowledge associated with biodiversity through a special law known as the Provisional Measures No. 2.186-16, of August 23, 2001, which aims to regulate access to genetic heritage ${ }^{4}$ and associated traditional knowledge. ${ }^{5}$ The protection of traditional knowledge is mainly facilitated through contracts of access, which enable third parties to obtain specific authorisation to gain access to traditional associated knowledge and/or components of genetic heritage for scientific research, bioprospecting and technological development purposes. ${ }^{6}$ Accordingly, the benefits arising from economic exploitation of a product or process developed from associated traditional knowledge must be shared in a fair and equitable way between the contracting parties. ${ }^{7}$ In addition, Article 31 of the Brazilian law states that any application for patent protection of an invention based on genetic resources and/or traditional knowledge should disclose the origin of such material and the associated traditional knowledge. ${ }^{8}$ This law particularly states that access to traditional knowledge must be authorised by the Genetic Heritage Management Council of Brazil, after prior informed consent is given by the holders of such knowledge. ${ }^{9}$ It means that no contract between the user and the provider can be enforced without the

\footnotetext{
${ }^{4}$ The term 'genetic heritage' is used by the Brazilian Provisional Measures 2, 186-16 as meaning 'information of genetic origin, contained in samples of all or part of plant, fungal, microbial or animal species, in the form of molecules and substances originating in the metabolism of these living beings, and in extracts obtained from in situ conditions, including domesticated, or kept in ex situ collections, if collected from in situ conditions, within the Brazilian territory, on the continental shelf or in the exclusive economic zone'.

${ }^{5}$ B O’Connor, 'Protecting Traditional Knowledge. An Overview of a Developing Area of Intellectual Property Law' (2003) 6 The Journal of World Intellectual Property 677, 691.

${ }^{6}$ Access \& Benefit-Sharing of Genetic Resources: Ways and Means for Facilitating Biodiversity Research and Conservation while Safeguarding ABS Provisions, Report of an international workshop in Bonn, Germany, held on 8-10 November 2005, $\mathrm{UNEP} / \mathrm{CBD} / \mathrm{WG}-\mathrm{ABS} / 4 / \mathrm{INF} / 10$.

${ }^{7}$ Brazilian Provisional Measures art 24. The benefits derived from the economic exploitation of a product or process developed from samples of the genetic heritage or associated traditional knowledge may consist of division of profits; payment of royalties; technology access and transfer; unrestricted licensing of products or services; and training of human resources.

${ }^{8}$ Brazilian Provisional Measures art 31.

${ }^{9}$ Brazilian Provisional Measures art 16.
} 
consent of the Management Council. ${ }^{10}$ The law has taken all possible measures to prevent unauthorised third parties from using indigenous and local communities' traditional knowledge. This relates to any activity involving the exploitation, transmission, disclosure, or re-transmitting of data/information comprising traditional knowledge. ${ }^{11}$ It also provides for sanctions including fines, the seizure of illegal material and products embodying unlawful material, the prohibition of distribution, the invalidation of patents or registrations, the loss of governmental incentives, and the like. ${ }^{12}$

Overall, the main aim of the Brazilian Provisional Measures is to regulate access to genetic heritage and associated traditional knowledge. ${ }^{13}$ One of the disadvantages of the law is that the protection is limited to the knowledge that is associated with Brazilian genetic resources and genetic heritage. The scope of the law should be extended to cover the situation when the traditional knowledge is conveyed through traditional cultural expressions and expressions of folklore. As it is stated:

A general notion of traditional knowledge might include not only knowledge itself, but also the expressions of the traditional knowledge, such as verbal or musical expressions, expressions by action (such as dances), whether or not reduced to a material form,

\footnotetext{
${ }^{10}$ Brazilian Provisional Measures art. 29. Contracts for Use of the Genetic Heritage and Benefit-Sharing shall be submitted to the Management Council for registration and shall only become effective once approved. Contracts for Use of the Genetic Heritage and Benefit-Sharing that are signed in a manner not conforming to the terms of this Provisional Measure and the regulations shall be null and devoid of legal effect.

${ }^{11}$ Art. 9 cited in Review of ExistingIintellectual Property Protection for Traditional Knowledge, Report of the Third Session of the Intergovernmental Committee on Intellectual Property and Genetic Resources, Traditional Knowledge and Folklore, WIPO Document, WIPO/GRTKF/IC/3/7, 6 May 2002 at 16, quoted in T Cottier and M Panizzon, Legal Perspectives on Traditional Knowledge: The Case for Intellectual Property Protection' (2004) 7 Journal of International Economic Law 372, 380.

${ }^{12}$ WIPO Doc.WIPO/GRTKF/IC/3/7, 6 May 2002 at 6. See also, S K Verma, above n 2, 765-805.

${ }^{13}$ Traditional knwoldge is defined by Article 7 (II) of the Brazilian Provisional Measures, as 'individual or collective information or practice of the indigenous community or local community, with real or potential value, associated to genetic resources'.
} 
and tangible expressions (such as drawings, paintings, carvings), musical instruments and architectural forms. ${ }^{14}$

Another limitation is that the Brazilian Provisional Measures are focused exclusively on protection against misappropriation of traditional knowledge. They do not provide any mechanism for the preservation and promotion of traditional knowledge. It is argued that any sui generis regime should have appropriate incentives for the recovery and protection of traditional knowledge and the promotion of the wider use of traditional knowledge and innovation systems, and should foster traditional research, innovation and development activities. ${ }^{15}$ It is therefore necessary to improve the legislation in effect in Brazil concerning access and benefit-sharing, especially in relation to the preservation and promotion of traditional knowledge, the promotion of research and the sustainable use of biodiversity. In addition, even though the Brazilian law discusses indigenous rights, it does not provide any specific definition of the term 'indigenous communities' nor of what is intended by 'community'. The definition could also extend to cover this element. Moreover, as discussed earlier, Article 31 of the law states that any application for patent protection of an invention based on genetic resources and/or traditional knowledge should disclose the origin of such material and the associated traditional knowledge. However, Article 8(4) of the law emphasises that protection provided under the law should not prejudice or limit the rights related to standard intellectual property as such. ${ }^{16}$ The above two provisions seem to be contradictory, as standard patent law does not require disclosure of the origin of the product. These issues need to be effectively addressed.

Peru promulgated special legislation in 2002 (Peruvian Law No 27,811), which aims to encourage the protection of indigenous knowledge as well as the wider application of knowledge and practices. ${ }^{17}$ The law recognises

\footnotetext{
${ }^{14}$ See WIPO/UNESCO Model Provisions for National Laws on the Protection of Expressions of Folklore Against Illicit Exploitation and Other Prejudicial Actions.

${ }^{15}$ B Tobin, 'Redefining Perspectives in the Search for Protection of Traditional Knowledge: A Case Study from Peru' (2001) 10 Review of European Community \& International Environmental Law 47, 61.

${ }^{16}$ M.M Tonye, 'Sui Generis Systems for the Legal Protection of Traditional Knowledge and Biogenetic Resources in Cameroon and South Africa' (2003) 6 The Journal of World Intellectual Property, 763- 771.

${ }^{17}$ Protection is conferred on collective knowledge which is not in the public domain. The aims of the regime are to: promote respect for and the protection, preservation, wider application and development of the collective knowledge of indigenous peoples; promote the fair and equitable distribution of the benefits derived from the
} 
indigenous peoples as the holders of traditional knowledge. ${ }^{18}$ It has adopted a broad definition of the term 'indigenous peoples' that are defined as 'aboriginal peoples holding rights that existed prior to the formation of the Peruvian State, maintaining a culture of their own, occupying a specific territorial area and recognizing themselves as such. The rural and native communities are included in the definition of indigenous peoples given by this Law. ${ }^{19}$ The law affirms the full right to register the collective knowledge of indigenous people, irrespective of whether collective knowledge is in the public domain or not. ${ }^{20}$ These registers include (i) a national register for knowledge that is in the public domain; (ii) a national register for confidential knowledge; and (iii) local registers organised in accordance with indigenous peoples' practices and customs. These registers not only facilitate the preservation of the traditional knowledge, but they also assist potential bioprospectors to locate the various sources and to avoid local patenting being carried out without the due authorisation. Moreover, the prior informed consent of the relevant community is one of the key factors in the Peruvian Law that allows indigenous communities to decide when, where and how their traditional knowledge can be accessed for commercial, industrial or scientific purposes. ${ }^{21}$ The law also requires bioprospectors to obtain a licence agreement to use the knowledge generated by indigenous communities. ${ }^{22}$ Additionally, signed written agreement for the use of collective knowledge is necessary to ensure that an adequate payment and an equitable distribution of

use of that collective knowledge; promote the use of the knowledge for the benefit of the indigenous peoples and mankind in general; ensure that the use of the knowledge takes place with the prior informed consent of the indigenous peoples; promote the strengthening and development of the potential of the indigenous peoples and of the machinery traditionally used by them to share and distribute collectively generated benefits under the terms of this regime; avoid situations where patents are granted for inventions made or developed on the basis of collective knowledge of the indigenous peoples of Peru without any account being taken of that knowledge as prior art in the examination of the novelty and inventiveness of the said inventions., see Article 5 of the Peruvian Law No 27,811.

${ }_{18}^{18}$ Peruvian Law arts 1, 3 and 42.

${ }^{19}$ Ibid art 2(a) .

${ }^{20}$ Ibid art 7 and Title VII.

${ }^{21}$ Ibid art 6. See also B O’Connor, above n 5, 693.

${ }^{22}$ Arts 6-8 of the Peruvian Law state that those interested in having access to collective knowledge for the purposes of scientific, commercial and industrial application shall apply for the prior informed consent of the representative organizations of the indigenous peoples possessing collective knowledge. 
the benefits derived from its use are shared. ${ }^{23}$ The scope of the Peruvian legislation is broad, and appears to include the preservation of traditional knowledge and the promotion of its wide use and development. In particular, Peruvian law has adopted a more comprehensive definition of collective knowledge, which includes the characteristics of such knowledge. Moreover, the creation of three registers ensures conservation and safeguarding of the collective knowledge of indigenous peoples and their rights to that knowledge. ${ }^{24}$ Nonetheless, the scope of Peruvian law is thus limited to traditional knowledge that is collective, accumulated and transgenerational; is created by indigenous peoples and communities; and concerns the properties, uses and characteristics of biodiversity components. ${ }^{25}$ This raises concerns as to whether the law would deny protection to traditional knowledge created by indigenous communities in the future. ${ }^{26}$

Panamanian Law No 20 of June 26, 2000, entitled the Special Intellectual Property Regime Governing the Collective Rights of Indigenous Peoples for the Protection and Defense of their Cultural Identity and their Traditional Knowledge, is similar to the Peruvian law. It is argued that the sui generis system of Panama constitutes probably the first comprehensive system of protection of traditional knowledge. ${ }^{27}$ The scope of protection is extended to customs, traditions, beliefs, spirituality, and folkloric and traditional expressions of indigenous communities. Specifically, Article 2 of the law defines collective indigenous rights as indigenous cultural and intellectual property rights that relate to art, music, literature, biological, medical and ecological knowledge and other subject matter and manifestations that have no known author or owner or date of origin, being the heritage of an entire indigenous people. The primary purpose of this law is to protect the collective intellectual property rights and traditional knowledge of indigenous peoples through the registration, promotion and commercialisation and marketing of their rights over their creations. ${ }^{28}$ Moreover, a licence agreement should be signed between the user and the provider to ensure that

\footnotetext{
${ }^{23}$ The agreement must provide for an initial payment and a percentage of no less than 5 per cent of the value, before taxes, of the gross sales resulting from the marketing of the products developed directly or indirectly from the said collective knowledge.

${ }^{24} \mathrm{M}$ Blakeney, 'Proposals for the Disclosure of Origin of Genetic Resources in Patent Applications' - WIPO/IP/GR/05/01.

${ }^{25}$ Intergovernmental Committee on Intellectual Property and Genetic Resources, Traditional Knowledge and Folklore, Fifth Session, Geneva, July 7 to 15, 2003WIPO/GRTKF/IC/5/8.

${ }^{26}$ Ibid.

${ }^{27}$ O'Connor, above n 5, 677-98.

${ }^{28}$ Panamanian Law art 1.
} 
the equitable distribution of the benefits derived is guaranteed. ${ }^{29}$ The scope of the legislation is very broad, as it appears to protect both traditional knowledge and expressions of traditional knowledge such as inventions, models, drawings and designs, innovations contained in pictures, figures, symbols, illustrations, old carved stones, and others. Even though the Brazilian and Peruvian laws consider both the genetic resources and the associated knowledge as subject matter for protection, Panamanian law does not mention the tangible material as a subject of protection. ${ }^{30}$

The Indigenous Peoples' Rights Act of 1997 of the Philippines acknowledges indigenous peoples' rights and provides for indigenous communities' rights to control 'access to ancestral lands, biological and genetic resources and indigenous knowledge related to these resources'. ${ }^{31}$ The Act provides indigenous peoples with rights to own and develop land and natural resources, to stay in territories, and to resettle in case of displacement due to natural catastrophe. It also provides them with rights to ancestral property and self-government. ${ }^{32}$ Under this law, access to biological resources would be subject to prior informed consent obtained in accordance with the customary laws of indigenous peoples and the licence agreement between the bioprospector and the Philippines' Government. ${ }^{33}$ The Act further states that prior informed consent must be obtained after full disclosure of the intent and scope of the activity, in a language and process understandable to the community. The Act also makes it mandatory that the communities must receive royalties from the income derived from any research conducted and publications resulting from the research. Section 34 provides that Indigenous Cultural Communities/Indigenous (ICC/IPs) are entitled to full recognition of the ownership, control and protection of their cultural and intellectual rights. The Act determines that indigenous communities and peoples have a right to their traditions and customs and to the restitution of intellectual property taken without their consent. Accordingly, full participation is awarded in all levels of decision-making affecting indigenous cultural communities and indigenous peoples' 'rights, lives and destinies'. ${ }^{34}$ To recognise full

\footnotetext{
${ }^{29}$ A percentage which shall not be less than ten per cent of the value, before tax, of the gross sales resulting from the marketing of goods developed on the basis of collective knowledge shall be set aside for the Fund for the Development of Indigenous Peoples, Verma, above n 2, 795.

${ }^{30}$ Tonye, above $\mathrm{n} 16$ at 764-74.

${ }^{31}$ Chapter III of the Philippines Act.

${ }^{32}$ Indigenous Peoples Rights Act at Ch.III, 7.

${ }^{33}$ The licenses are only granted upon the written consent of a knowledge holding community; see Cottier and Panizzon, above n 11, 371.

${ }^{34}$ Section 16 of the Philippines Act.
} 
ownership, control and protection of their cultural and intellectual rights, a National Commission on indigenous peoples has been established. ${ }^{35}$ Enforcement of indigenous peoples' rights is also to be undertaken according to customary law. ${ }^{36}$

The Philippines' Act is the first comprehensive law to recognise the rights of the indigenous peoples of the Philippines that includes not only the rights of indigenous peoples over their ancestral domain but their rights to social justice and human rights, self governance and empowerment, as well as cultural integrity. ${ }^{37}$ Specifically, the most significant fact here is that indigenous rights have been recognised by the Constitution of the Philippines, which acknowledges 'indigenous cultural communities' and rights to 'ancestral lands' and 'ancestral domain'. Article 12, Section 5 provides:

The State, subject to the provisions of this Constitution and national development policies and programs, shall protect the rights of indigenous cultural communities to their ancestral lands to ensure their economic, social and cultural well-being.

One of the disadvantages of the Act is that even though access is subject to prior informed consent, the term 'prior informed consent' has not been defined by the Act. The national law needs to clarify and define obligations requiring 'prior informed consent' and the means required for this to be achieved.

This comparative approach shows that the countries have taken diverse approaches to identifying and acknowledging the rights of indigenous peoples. In particular, it is clear that all sui generis measures have established certain basic elements of an access system such as procedures for obtaining prior informed consent (PIC) and mechanisms for benefit-sharing. They also specify the authorities competent to grant access. There is growing recognition of the significant role that a sui generis system is able to play in strengthening the capacity of indigenous communities to protect and renew

\footnotetext{
${ }^{35}$ Chapter VII of the Philippines Act.

${ }^{36}$ Chapter IX of the Philippines Act.

${ }^{37}$ R Sidchogan-Batani, 'Implementation of the Indigenous Peoples Rights Act (IPRA) in the Philippines: Challenges and Opportunities', background paper presented for the Expert Seminar on Treaties, Agreements and Other Constructive Arrangements between States and Indigenous Peoples, Geneva, 15-17 December 2003.
} 
their cultural and biological creativity nation-wide. Traditional knowledge has a very particular nature and the development of sui generis systems seems to be the logical answer to the problem. In other words, a sui generis form of protection allows a very wide choice of legal mechanisms under national law which may be precisely tailored to the local interests, traditions, and the culture of the particular country. In particular, sui generis law can be made flexible by acknowledging the specific requirements of the country, and its peoples' needs and their interests. ${ }^{38}$

Despite the great advances that they have brought about in protecting traditional knowledge of indigenous people, the sui generis laws still reflect certain inherited problems. For example, even though the benefits of a sui generis option are substantial for any country with a rich traditional knowledge heritage, this option has certain inadequacies in coping with various matters such as the limited protection outside the country of origin, the diversity of the subject matter, the identification of the owner of the rights, the procedures and formalities for the acquisition and maintenance of the rights conferred and the limits imposed on the rights. ${ }^{39}$ For example, sui generis law may create problems in identifying the owner of the knowledge if the knowledge belongs to more than one community or a particular territory or a region. Obviously, it may then become necessary to establish a system of geographical and administrative definitions of communities. ${ }^{42}$

In addition to that, considerable overlap between existing intellectual property laws and sui generis laws leads to confusion for litigants and uncertainty in the law. It is argued that:

Sui generis protection relates to an encompassing yet specific subject matter which does not exactly fit into to the copyright or patent framework Domestic systems may require specific protection so as to draw level with increasing endeavours in new technologies. ${ }^{40}$

\footnotetext{
${ }^{38}$ Peggy Fairbairn-Dunlop, 'Challenges in the Traditional Knowledge-IPR debate', Paper for Chennai Follow-Up Meeting: Utilizing Science and Technology for Women's Economic Empowerment: Progress and New Challenges, Seoul, Republic of Korea, Nov 2000, UNESCO/UNDP.

${ }^{39}$ IPTF Luncheon, 'Is a Sui generis System Necessary: Benefit Sharing Agreements' $<$ http://www.iipi.org/speeches/NewYork011404.pdf $>$ at 21 October 2007.

${ }^{40} \mathrm{G}$ Westkamp, 'Trips Principles, Reciprocity and the Creation of Sui-Generis-Type Intellectual Property Rights for New Forms of Technology' (2003) Journal of World Intellectual Property 830.
} 
Standard intellectual property has never applied to all forms of creativity and inventions.] From that perspective, rightsholders are necessarily those who created or invented the intellectual property or have acquired it by transfer. ${ }^{41}$ In contrast, sui generis law does not protect works or inventions, but specific subject matter. For example, sui generis law imposes disclosure obligations in relation to patents for inventions derived from genetic resources and associated traditional knowledge. A general obligation to disclose any traditional knowledge upon which an invention is based would help to prevent patents being wrongfully granted. Nevertheless, there is a concern as to the extent to which an obligation to disclose the origin of biological materials would be consistent with the TRIPS Agreement, in particular with article 27.1.

In essence, 'sui generis' refers to rights that are designed to be unique for a specific purpose and are not covered by existing legal systems. ${ }^{42}$ Some argue that sui generis rights are alternative models created outside the prevailing intellectual property regime. ${ }^{43}$ This means that the protection provided by sui generis laws has been considered as an alternative to existing intellectual property regimes. If that is the case, any national or regional sui generis system that protects traditional knowledge may need to interact with existing intellectual property regimes. However, in reality, the question is whether sui generis law should follow the existing intellectual property regimes or whether, instead, it should provide flexibility in providing more extensive protection on the basis of the special needs of individual countries, depending on their cultural and political conditions. Otherwise, the question is whether some of the parameters in the typical systems of protection may require modification. These issues are always debatable and have led to confusion in some countries. For example, as we discussed before, Article 31 of the Brazilian law states that any application for patent protection of an invention based on genetic resources and/or traditional knowledge should disclose the origin of such material and the associated traditional knowledge. However, Article 8(4) of the same law emphasises that protection provided under the law should not prejudice or limit the rights related to standard intellectual property as such. ${ }^{44}$ This seems to be contradictory, as standard patent law

\footnotetext{
${ }^{41}$ Ibid.

${ }^{42}$ B Harvey and D Greer, Blue Genes: Sharing and Conserving the World's Aquatic Biodiversity (2004).

${ }^{43}$ S Ragavan, 'Protection of Traditional Knowledge' at $<$ http://www.law.ou.edu/faculty/facfiles/protection_of_traditional_knowledge.pdf $>$ at 3 July 2007.

${ }^{44}$ Tonye, above n 16, 763-771.
} 
does not require disclosure of the origin of the product. These issues require to be effectively addressed. A key legal and practical issue is, therefore, how to achieve balance between existing intellectual property law and sui generis laws granted under national systems, or to ensure effective articulation of national systems.

\section{Regional INITIATIVES}

There has been considerable debate in relation to the need to develop regional regimes among different nations in order to protect indigenous rights, to jointly conserve biodiversity, to achieve sustainable use, and to promote equitable benefit-sharing, particularly through appropriate regional models. The strengthening cooperation among nations in this area would seem to be the most effective strategy for achieving relevant national objectives. Regional experiences should be encouraged and supported, which would make it easier to find a holistic comprehensive system when joint processes are initiated. It is suggested here that a regional regime would optimise the possibility for cooperation among the Member States to manage biodiversity; to maximise the efficient use of resources; and to ensure that the benefits from their exploitation are fairly and equitably shared in the region. ]

Although protection of indigenous knowledge has become the particular property of sovereign countries, this issue has gained momentum in a more generalised (supra-national) regional context. It is suggested here that the underlying rationale for developing such regulatory regional regimes is the specific aim of achieving a more equitable (as well as socially just) sharing of the benefits that flow from the use of traditional knowledge and expressions of indigenous culture. Regional regimes could also strength the regional cooperation among Member Countries on matters of mutual interest in relation to the conservation and the sustainable use of genetic resources and their derivatives in the region. When countries work regionally to achieve a goal, the countries of the region recognise that regional cooperation is their own responsibility and act accordingly.

\section{Regional Model LaW for Africa - OAU Model LAW 200}

This model law was developed as a direct response to the decision taken and the directive given by the OAU (Organisation of African Unity) Council of 
Ministers in $1988 .^{45}$ The aim of the Model Law was to protect traditional knowledge as a means of supporting traditional knowledge-based communities' livelihoods and cultures. Community knowledge or indigenous knowledge is defined in the Law as 'the accumulated knowledge that is vital for conservation and sustainable use of biological resources and/or which is of socioeconomic value, and which has been developed over the years in indigenous/local communities' ${ }^{46}$ The Model Law includes a specific section on community rights ${ }^{47}$ and, accordingly, local communities have the right to refuse access to their biological resources, innovations, practices, knowledge and technologies where such access will be detrimental to the integrity of their natural or cultural heritage. ${ }^{48}$ Furthermore, the community intellectual rights of the local communities, including traditional professional groups and particularly traditional practitioners, at all times remain inalienable, and shall be further protected under the mechanism established by this legislation. ${ }^{49}$ In terms of scope, the OAU Law applies to:

(a) Biological resources both in-situ and ex-situ including plant varieties;

(b) The derivatives of the biological resource;

(c) Community traditional knowledge, innovations, technologies and practices; and

(d) Local and indigenous farming communities and farmers and plant breeders. ${ }^{50}$

The Model Law requires the prior informed consent of both the State and the local community before access can be granted to biological resources. ${ }^{51}$ It specifies provision for consultation with the concerned communities on applications being made for access. The responsibility to ensure appropriate consultation rests with the National Competent Authority. The access permit should be subject to payment - made before commencement of collection - of a fee, the sum of which will depend on whether or not the collection is to be used for commercial purposes, and the number of samples, the area of

\footnotetext{
${ }^{45}$ M Sharma, 'A Model Law' (2004) 21 Frontline

$<$ http://www.hinduonnet.com/fline/fl2105/stories/20040312000106500.htm > at 21

April 2007.

${ }^{46}$ OAU Model Law art 1.

${ }^{47}$ Sharma, above $\mathrm{n} 48$, PART IV.

${ }^{48}$ OAU Model Law art 19.

${ }^{49}$ OAU Model Law art 23.

${ }^{50}$ Ibid art 2.

${ }^{51}$ Ibid art 3.
} 
collecting, the duration of collection and whether or not the collector is granted exclusive rights. ${ }^{52}$

In short, the OAU Model Law recognises the importance of indigenous knowledge and the rights of local communities. These communities are recognised as central to the traditional knowledge and utilisation of the biodiversity. It particularly gives special attention to the indigenous knowledge system, conservation and sustainable use of biological resources, community rights, equitable sharing of benefits and national sovereignty consistent with the provisions of the Convention on Biological Diversity (CBD). One of the positive elements of the regime is that it prompts each African country to make positive efforts to improve its overall capacity to challenge and prevent the misappropriation of traditional knowledge. It also brings closer collaboration and cooperation among African nations in terms of protecting their traditional knowledge. This regional regime assists member countries to formulate their national legislation in accordance with their national interest, economic development objective, and political orientation.

\section{Andean Pact Decision 391}

In 1996, the Andean Community Member Countries (Bolivia, Colombia, Ecuador, Peru and Venezuela) adopted Decision 391: Common System on Access to Genetic Resources, which is the first sub-regional access and benefit-sharing legislative measure in response to Article 15 of the CBD. The Decision 391 established a common regime regarding access to genetic resources and their derivatives within the Andean region. The Decision defines an indigenous, afro-American or local community as a human group distinguished from other sectors of the national population by virtue of its social, cultural and economic conditions. ${ }^{53}$ One of the objectives of the Decision is to establish a basis for the recognition and appreciation of genetic resources, their derivatives and related intangible components, particularly where indigenous, afro-American and local communities are involved. ${ }^{54}$ The regime ensures that the resultant benefits are shared with the countries from

\footnotetext{
${ }^{52}$ Ibid art 12.

${ }^{53}$ Andean Pact Decision 391 art 1 . This group is additionally defined as being wholly or partially governed by its own customs or traditions or by special legislation and retains, in whole or in part, its own social, economic, cultural and political institutions regardless of its legal status.

${ }^{54}$ Ibid art 2(b).
} 
which genetic resources and biological materials are collected. It provides a defensive protection for associated intangible components by denying intellectual property rights over products obtained or developed by using information on associated intangible components accessed in a manner contrary to the provisions of this Decision. It also regulates access to genetic resources of member states in:

(a) establishing the conditions for just and equitable participation in the benefits of the access;

(b) establishing the foundations for the recognition and valuation of the genetic resources and their by-products and of their associated intangible components, especially when native, AfroAmerican or local communities are involved;

(c) promoting conservation of the biological diversity and the sustainable use of the biological resources that contain genetic resources;

(d) promoting the consolidation and development of scientific, technological and technical capacities at the local, national and subregional levels; and

(e) strengthening the negotiating capacity of the Member Countries ${ }^{55}$

One of the key elements of the regional regime is to develop the law and policies within the region to follow a specific procedure in relation to a matter of common concern. ${ }^{56}$ It has been argued, in this respect, that:

Since these countries are neighbours sharing many of the same genetic resources, establishing a region-wide access and benefit sharing regime makes it more difficult for bioprospectors to play one country off against its neighbours to secure overly favourable conditions. $^{57}$

\footnotetext{
55 Ibid art 2.

${ }^{56} \mathrm{~K}$ Kariyawasam, 'Access to Biological Resources and Benefit-Sharing: Exploring a Regional Mechanism to Implement the Convention on Biological Diversity (CBD) in SAARC Countries' (2007) 29 EIPR 325, 331.

${ }^{57}$ G Dutfield, The Andean Pact Common System on Access to Genetic Resources: A Commentary (1997) available at $<$ http://www.redbio.org/portal/encuentros/enc_2001/minicursos/pdf/mc_15/16.Co mments\%20andpact.pdf $>$ at 11 May 2007.
} 
Decision 391 recognises that all member countries have sovereign rights over their genetic resources and the by-products derived from them. ${ }^{58}$ It also stipulates that a special regime or a harmonization of national legislation should be implemented by member countries of the Andean Community for the protection of intangible components associated with the genetic resources. ${ }^{59}$ The Andean countries use Decision 391 itself as a mechanism to regulate access to and protection of traditional knowledge and the member countries are currently at varying stages of the legislative process. This regional regime provides a challenging opportunity for Andean member countries to reflect and recognise their cultural heritage in the laws of their modern national states.

\section{The ASEAN Regional Framework AgReEment}

This Agreement recognises, respects, preserves and maintains the knowledge, innovations and practices of indigenous peoples and local communities embodying traditional lifestyles and their natural resources, including genetic resources. ${ }^{60}$ One of the objectives of the Agreement is to protect the traditional knowledge of indigenous peoples and local communities, and to facilitate fair and equitable sharing of benefits with the said communities where traditional knowledge is utilised. ${ }^{61}$ It recognises the indigenous peoples and local communities as the legitimate users and custodians of biological and genetic resources, and creators of traditional knowledge. ${ }^{62}$ The law also emphasises that prior informed consent is necessary before access is granted to genetic resources and that it should be gained with the active involvement of indigenous peoples and local communities. ${ }^{63}$ The law requires all resource providers to be participants in the negotiation of benefits. This is particularly the case for 'indigenous peoples and local communities embodying traditional lifestyles' who must be informed of both benefits and risks potentially arising from the use of the resource. ${ }^{64}$ The Agreement further emphasises that benefit-sharing arrangements must not impede 'traditional

\footnotetext{
${ }^{58}$ Andean Pact Decision 391 arts 5 and 6.

${ }^{59}$ Ibid para 8 .

${ }^{60}$ ASEAN Regional Framework Agreement art 1.

${ }^{61}$ Ibid art 2.

${ }^{62}$ Ibid art 11.

${ }^{63}$ Ibid art 10.

${ }^{64}$ Ibid art 11.
} 
knowledge systems and practices of indigenous peoples and local communities'. 65

\section{MODEL LAWS OF THE PACIFIC}

The purpose of the law on Traditional Ecological Knowledge and Innovations and Practices, 2000, is to prevent the unauthorised use of traditional ecological knowledge, innovations and practices, and to ensure equitable sharing of benefits derived from the use of such knowledge, innovations and practices. The Model Law encompasses not only knowledge, but also products (such as innovations ${ }^{66}$ ) and practices based on that knowledge. The law also states that access to traditional knowledge; innovation and practices of indigenous and local communities should be subject to prior informed consent of the owners of the knowledge. ${ }^{67}$ The user of the knowledge must also enter into an access and benefit-sharing agreement with the owner or co-owners. ${ }^{68}$ All traditional ecological knowledge may be registered in a national registry and if the knowledge is owned by two or more countries or by the Pacific Region as a whole, the regional register can be employed for the registration. ${ }^{69}$

The Model Law for the Protection of Traditional Knowledge and Expressions of Culture, 2000 provides protection to the traditional cultural rights that exist in traditional knowledge and expressions of culture whether they are in material form or not. ${ }^{70}$ Part 4 of the law provides that a prospective user of traditional knowledge and expressions of culture can seek prior informed consent from either the Cultural Authority or directly from the owners of the knowledge, ${ }^{71}$ where the prior informed consent is to be evidenced in the form

\footnotetext{
${ }^{65}$ Ibid.

${ }^{66}$ Innovation means biological material - defined as any part, including the genes, of a plant, animal or microorganism - rendered of any or of enhanced use or value through the application of traditional ecological knowledge. See section 2 of the Model Law.

${ }^{67}$ Model Law of the Pacific art 10.

${ }^{68}$ Ibid art 10.

${ }^{69}$ Ibid art 9. Accordingly, each national government in respect of a national register, and the Regional Coordinator in respect of a regional register, must put in place rules to establish and maintain a register and to provide for confidentially.

${ }^{70}$ Model Law for the Protection of Traditional Knowledge and Expressions of Culture, 2000 clause 8.

${ }^{71}$ Clause 25 provides that if a prospective user directly deals with traditional owners, he or she must: (a) advise the Cultural Authority that he or she sought the prior
} 
of an 'authorised user agreement' ${ }^{72}$ If an authorised user agreement exists between the prospective user and the traditional owners it appears that the traditional owners are deemed to have given their prior informed consent to the proposed use. ${ }^{73}$ If the traditional owners cannot be identified or if there is a dispute about ownership, customary law and practice must be applied to the matter concerned. ${ }^{74}$ The Cultural Authority is the owner of the traditional knowledge or expression of culture if the owners cannot be identified, and any benefit derived from that agreement must be used for traditional cultural development purposes. ${ }^{75}$ This Model Law also provides for moral rights of authors, which are the right of attribution, and rights against false attribution and derogatory treatment in respect of traditional knowledge and expressions of culture. ${ }^{76}$ However, the above model laws are [this Model Law is?] yet to be introduced.

In short, the primary purpose of all these regional regimes is to strengthen regional cooperation among member countries on matters of mutual interest in relation to the legal problems, practical concerns and difficulties faced by

informed consent of the traditional owners; and (b) provide the Cultural Authority with a copy of the authorised user agreement between the prospective user and the traditional owners for comment and advice about other traditional owners. This requirement cannot be contracted out of. Further, if a copy of the agreement is not provided to the Cultural Authority, clause 25(6) renders the agreement null and void. The Cultural Authority must also be provided with a copy of the signed authorised user agreement, for entry in the register within 28 days after the agreement comes into force.

${ }^{72}$ Model Law for the Protection of Traditional Knowledge and Expressions of Culture, 2000 Part 4.

${ }^{73}$ Ibid cl 23(1). An authorised agreement must include terms and conditions, including: (a) sharing of financial and other benefits arising from the use of the traditional knowledge or expressions of culture; (b) providing compensation, fees, royalties or other payments for the use; (c) determining whether the use will be exclusive or non-exclusive; (d) specifying duration of the use to be allowed and rights of renewal; (e) indicating disclosure requirements in relation to the use; (f) the possible sharing by the traditional owners of any intellectual property rights arising from the use of the traditional knowledge and expressions of culture; (g) indicating access arrangements for the traditional owners; (h) specifying education and training requirements for the applicant; (i) determining controls on publication; (j) specifying whether the rights arising under the agreement can be assigned; ( $\mathrm{k}$ ) indicating choice of law in relation to dispute under the agreement; (1) respecting moral rights of the traditional owners.

${ }^{74}$ Ibid cl 18.

${ }^{75} \mathrm{Ibid} \mathrm{cl}$ 19(1) and (2).

${ }^{76}$ Ibid Part 3. 
indigenous communities in the protection of their intellectual property. All regional regimes encourage their member countries to design and implement joint programs for the protection of indigenous rights for the mutual benefit of all. They also require member countries to agree on specific adjustments to national laws and regulations in order to regulate and protect their knowledge and associated biological resources from unfair exploitation. It is clear, in this regard, that national efforts can be complemented by a legally binding regional regime which aims at promoting cooperation among its own members.

\section{CONCLUSION}

In short, the establishment of national and regional initiatives is now acknowledged as the most appropriate means of ensuring both national and regional priorities for the protection of traditional knowledge. In particular, regional measures would optimise the possibility for cooperation among the member states to manage biodiversity; to maximise the efficient use of resources; and to ensure that the benefits from their exploitation are fairly and equitably shared between indigenous communities. It has been suggested here that these laws can be developed taking into account the particular cultural, social, political and economic diversity of member countries. Both national and regional regimes are more likely to succeed in and between states that possess similar cultures, economies, social status, and ecologies. Such an approach - one that acknowledges national diversity - would indeed optimise the possibility for cooperation among the Member States to manage biodiversit,; to maximise the efficient use of resources, and to ensure that the benefits from their exploitation are fairly and equitably shared in the region. It is hoped that this article has contributed to, and enhanced, the debate on what should be the most effective and appropriate regulatory legal frameworks for the protection of the intellectual property of indigenous peoples. 

